\title{
Pengaruh Return on Asset, Return on Equity dan Earning Per Share Terhadap Harga Saham pada Perusahaan Sektor Barang Konsumsi Yang Terdaftar di Bursa Efek Indonesia
}

\author{
Wirda Lilia*, A. Surya Raj, Jesica, Faren Goh \\ Faculty of Economy, University of Prima \\ *Correspondenceemail: liliawirda@ymail.com,rsurya079@gmail.com, jesicachung11@gmail.com, farengoh20@gmail.com
}

\begin{abstract}
Abstrak. Penelitian yang dilakukan di Perusahaan Sektor Barang Konsumsi bertujuan menganalisis Pengaruh Return on Asset (ROA), Return on Equity (ROE) dan Earning Per Share (EPS) Terhadap Harga Saham pada Perusahaan Sektor Barang Konsumsi yang Terdaftar di Bursa Efek Indonesia. Populasi penelitian sebanyak 41 perusahaan dan hanya 21 perusahaan yang memenuhi kriteria sebagai sampel menggunakan teknik purposive sampling. Metode penelitian menggunakan Analisis regresi linier berganda dengan uji asumsi klasik. Hasil penelitian dari uji F di peroleh bahwa Return on Asset (ROA), Return on Equity (ROE) dan Earning Per Share (EPS) berpengaruh Terhadap Harga Saham pada Perusahaan Sektor Barang Konsumsi yang Terdaftar di Bursa Efek Indonesia. Pada uji t variabel Return on Asset tidak berpengaruh terhadap harga saham pada perusahaan barang konsumsi yang terdaftar di Bursa Efek Indonesia. Return on Equity berpengaruh terhadap harga saham pada perusahaan barang konsumsi yang terdaftar di Bursa Efek Indonesia. Earning Per Share berpengaruh terhadap harga saham pada perusahaan barang konsumsi yang terdaftar di Bursa Efek Indonesia.
\end{abstract}

Kata Kunci: Return on Asset; Return on Equity; Earning Per Share; Harga Saham

Abstract. The research carried out in the Consumer Goods Sector Company aims to analyze the Effects of Return on Assets, Return on Equity and Earning Per Share on Share Prices in Consumer Goods Sector Companies Listed on the Indonesia Stock Exchange. The research population is 41 companies and only 21 companies that meet the criteria as a sample using purposive sampling technique. The research method uses multiple linear regressionianalysis with the classic assumption test. The results of the F test are obtained that Return on Assets, Return on Equity and Earning Per Share affect the Stock Prices of Consumers' Goods Sector Companies Listed on the Indonesia Stock Exchange. In the t test the variable Return on Assets does not affect the stock price of consumer goods companies listed on the Indonesia Stock Exchange. Return on Equity affects stock prices on consumer goods companies listed on the Indonesia Stock Exchange.Earning Per Share affects the price of shares in consumer goods companies listed on the Indonesia Stock Exchange.

Keywords: Return on Asset; Return on Equity; Earning Per Share; share price

\section{PENDAHULUAN}

Perusahaan barang konsumsi pada saat ini banyak menarik minat para pelaku bisnis untuk ikut serta terjun ke bisnis ini. Banyak perusahaan sektor barang konsumsi saling bersaing untuk memajukan usahanya. Persaingan ketat juga dihadapi perusahaan di Indonesia mengakibatkan perusahaan barang konsumsi harus melakukan segala cara untuk terus tumbuh dan berkembang serta membutuhkan dana cukup besar untuk kegiatan usahanya. Kondisi ini mendorong perusahaan di Indonesia untuk mencari sumber pembiayaan yang dapat menyediakan dana dengan jumlah cukup besar dan dana ini akan digunakan untuk peningkatan produksi serta kegiatan perusahaan operasional lainnya sehingga perusahaan memilih untuk memasuki pasar modal sebagai salah satu alternatif sumber dana terbaik selain dari perbankan. Di pasar modal perusahaan barang konsumsi melakukan penjualan saham perusahaannya.

Menurut Ika (2015), Harga saham yang telah beredar di pasar modal akan berubah - ubah seiring berjalannya waktu ke waktu. Harga saham dapat berubah naik turun dalam hitungan waktu cukup cepat. Hal ini tergantung permintaan dan penawaran antara pembeli dan penjual saham yang ada di pasar modal. Ircham (2014), menyatakan harga saham mencerminkan salah satu indikator keberhasilan pengelolaan perusahaan yang baik maka saham perusahaan tersebut akan banyak diminati oleh para investor di Indonesia. Salah satu cara dalam menilai perusahaan yang berpengaruh pada harga saham, maka investor dapat melakukan pengukuran terhadap Return on Asset, Return on Equity dan Earning Per Share.

Return on Asset digunakan sebagai suatu alat ukur kemampuan perusahaan secara keseluruhan dalam menghasilkan keuntungan dengan total aktiva yang tersedia di dalam perusahaan. Menurut Fauza (2016), semakin tinggi Return on Asset yang menunjukkan kemampuan perusahaan dalam menghasilkan laba besar maka semakin harga saham dapat naik. Nur'aidawati (2018), menyatakan bahwa semaikan tinggi nilai Return on Asset akan berdampak pada harga saham dipasar modal juga akan semakin tinggi. Investor selalu memandang perusahaan memiliki prospek bagus di masa mendatang jika harga saham perusahaan bisa tinggi di mana laba yang dihasilkan perusahaan meningkat dibandingkan tahun sebelumnya. Apabila permintaan 
saham banyak, maka harga saham akan meningkat.

Return on Equity digunakan untuk mengukur kemampuan perusahaan dalam menghasilkan laba bersih setelah pajak berdasarkan modal sendiri.Return on Equityjuga berpengaruh terhadap harga saham. Menurut Alipudin (2016), Semakin tinggi nilai Return on Equity maka semakin baik nilai kinerja perusahaan sehingga harga saham semakin tinggi pula.Laba perusahaan diharapkan setiap periode mengalami peningkatan, sehingga estimasi laba diketahui

Menurut Rahmadewi (2018), semakin tinggi nilai Earning Per Share maka harga saham cenderung naik. Earning Per Share yang tinggi dapat mendorong investor untuk menambah jumlah modal yang ditanamkan di perusahaan tersebut. Zulfi (2016) menyatakan semakin tinggi Eaning Per Share perusahaan menunjukkan semakin besar laba yang akan diterima investor dari investasinya tersebut. Oleh karena itu, dengan mengetahui Earning Per Share suatu perusahaan maka investor dapat menilai potensi pendapatan yang diterimanya dengan melakukan pembelian atas saham perusahaan.

\section{METODE}

\section{Jenis Penelitian}

Penelitian ini dilakukan pada perusahaan sektor barang konsumsi yang terdaftar di Bursa Efek Indonesia. Penelitian ini menggunakan metode penelitian kuantitatif.Data kuantitatif dalam penelitian ini menggunakan tipe data sekunder yaitu laporan keuangan pada perusahaan sektor barang konsumsi yang terdaftar di Bursa Efek Indonesia. Jenis penelitian pada penelitian ini adalah penelitian eksplanatori.

\section{Populasi dan Sampel}

Populasi dalam penelitian ini adalah perusahaan sektor barang konsumsiyang terdaftar di Bursa Efek Indonesia dan laporan keuangan yang digunakan bersumber dari www.idx.co.id. Berdasarkan populasi yang sudah ditentukan dalam penelitian ini, terdapat 41 populasi yang terdaftar di Bursa Efek Indonesia.

Sampel adalah bagian dari populasi yang diambil berdasarkan kriteria yang telah ditentukan oleh peneliti.Teknik sampling ini menggunakan metode sampling purposive. Berdasarkan metode sampling purposive kriteria yang akan digunakan dalam penelitian ini terdaftar di Bursa Efek Indonesia, laporan keuangan diterbitkan secara rutin. Terdapat 21 sampel perusahaan yang memenuhi syarat dalam penelitian ini.

\section{Return On Asset}

Murhadi (2013) menyatakan, Return on Asset adalah seberapa besar return yang dihasilkan atas setiap rupiah uang yang ditanamkan dalam bentuk asset perusahaan. Return On Asset memiliki skala rasio :

\section{ROA $=\frac{\text { Net Income }}{\text { Total Asset }}$}

\section{Return on Equity}

Kasmir (2014) menyatakan, hasil pengembalian ekuitas atau Return on Equity atau rentabilitas modal sendiri merupakan rasio untuk mengukur laba bersih sesudah pajak dengan modal sendiri.Return on Equity memiliki skala rasio :

$R O E=\frac{\text { Earning After Interest and Tax }}{\text { Equity }}$

\section{Earning per Share}

MenurutFahmi (2014) Earning Per Share atau pendapatan per lembar saham adalah bentuk pemberian keuntungan yang diberikan kepada para pemegang saham dari setiap lembar saham yang dimiliki :

$$
\text { EPS }=\frac{\text { Earning After Tax }}{\text { Jumlah Saham Beredar }} \times 100 \%
$$

\section{Harga Saham}

Harga Saham adalah harga perlembar saham yang dijual belikan di pasar modal.Indikator harga saham berupa penutupan tahunan.

\section{HASIL DAN PEMBAHASAN}

Adapun data penelitian yang berguna untuk mengetahui pengaruh Return on Asset, Return on Equity dan Earning Per Share Terhadap Harga Saham padaPerusahaan Sektor Barang Konsumsi yang Terdaftardi Bursa Efek Indonesia dilihat dari nilai minimum,nilai maximum, mean dan std deviation dapat dilihat dariTabel berikut :

Tabel 1.Statistik Deskriptif

Descriptive Statistics

\begin{tabular}{cc|c|c|c|c} 
& $\mathrm{N}$ & Min & Max & Mean & Std. Deviation \\
\hline ROA & 105 & .65 & 52.67 & 11.8413 & 10.72607 \\
\hline ROE & 105 & 1.91 & 143.53 & 23.6581 & 32.51806 \\
\hline EPS & 105 & 468.37 & 1095284.68 & 41329.8923 & 134010.64200 \\
\hline Harga Saham & 105 & 63.00 & 390000.00 & 8825.8000 & 38777.09878 \\
\hline Valid N (listwise) & 105 & & & & \\
\hline
\end{tabular}


1. Variabel Return on Asset dengan sampel sebanyak 105 mempunyai nilai minimum 0,65 di PT. Budi Starch \& Weetener Tbk tahun 2015 dan nilai maximum 52,67 pada PT. Multi Bintang Indonesia Tbk tahun 2017 sedangkan nilai mean 11,8413 serta std. deviation 10,72607.

2. Variabel Return on Equity dengan sampel sebanyak 105 mempunyai nilai minimum 1,91 di PT. Budi Starch \& Weetener Tbk tahun 2015dan nilai maximum 143,53 pada PT. Multi Bintang Indonesia Tbk tahun 2014 sedangkan nilai mean 23,6581 serta std. deviation 32,51806.

3. Variabel Earning Per Share dengan sampel sebanyak 105 mempunyai nilai minimum 468,37PT. Budi Starch \& Weetener Tbk tahun 2015 dan nilai maximum 1095284,68Pada PT. Chitose Internasional Tbk tahun 2017 sedangkan nilai mean 41329,8923 serta std. deviation 134010,64200.

4. Variabel Harga Saham dengan sampel sebanyak 105 mempunyai nilai minimum 63,00 di PT. Budi Starch \& Weetener Tbk tahun 2015 dan nilai maximum390000,00 pada PT. Delta Djakarta Tbk tahun 2014 sedangkan nilai mean 8825,8000 serta std. deviation 38777,09878 .

\section{Uji Asumsi Klasik \\ Uji Normalitas}

Menurut Ghozali (2018), Uji normalitas bertujuan untuk menguji apakah data residual telah berdistribusi secara normal atau tidak. Penelitian ini menggunakan analisis histogram dan normal probability plot. Berikut tampilan kedua grafik tersebut:

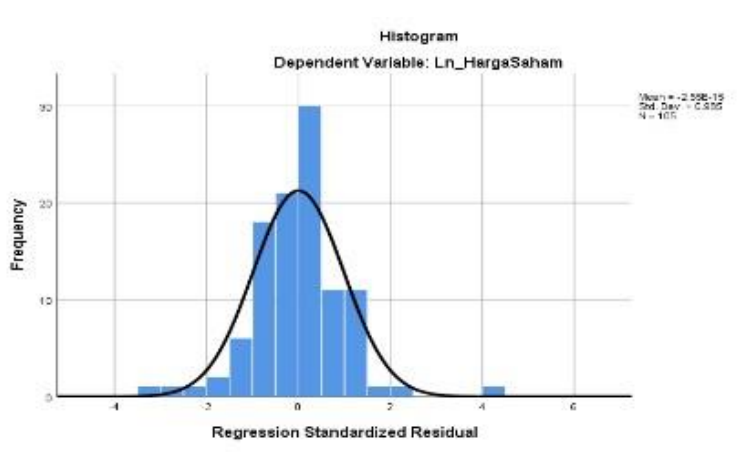

Gambar 1. Histogram Sesudah Transformasi

Dari grafik Histogram diatas, menunjukkan data Return on Asset, Return on Equity, Earning Per Share dan Harga Saham beresidual dengan distribusi normal karena dapat dilihat dari arahhistogram yang tidak miring kekananmaupun ke kiri dan membentuk lonceng terbalik. Grafik Normal Probability Plot dapat disajikan pada Gambar 2 berikut:

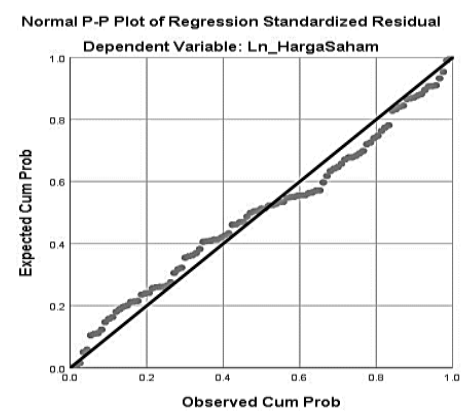

Gambar 2. Normal Probability Plot Sesudah Transformasi

Dari shasil normal probability plot menunjukkantitik-titik mendekati garis diagonal sehingga dataterdistribusinormal.Penelitian ini menggunakan uji normalitas dengan menggunakan statistik nonparametrik Kolmogorov Smirnov Test sehingga pedoman pengambilan keputusan data mendekati ataumerupakan distribusi normal dengansyarat sebagai berikut:

1. Jika nilai signifikan $>0,05$ maka distribusi normal,

2. Jika nilai signifikan $<0,05$ maka distribusi tidak normal

Tabel 2. One-Sample Kolmogorov-Smirnov Test Sesudah Transformasi

One-Sample Kolmogorov-Smirnov Test

\begin{tabular}{llr}
\hline $\mathrm{N}$ & & 105 \\
\hline Normal Parameters $^{\mathrm{a}, \mathrm{b}}$ & Mean & .0000000 \\
& Std. Deviation & .88818644 \\
\hline Most Extreme Differences & Absolute & .085 \\
\cline { 2 - 3 } & Positive & .085 \\
& Negative & -.063 \\
\hline Test Statistic & & .085 \\
\hline Asymp. Sig. (2-tailed) & & $.061^{\mathrm{c}}$ \\
\hline
\end{tabular}
a. Test distribution is Normal.
b. Calculated from data.
c. Lilliefors Significance Correction.

Berdasarkan Tabel 2 pengujian One-Sample Kolmogorov-Smirnov Test untuk data Return on Asset, Return on Equity, Earning Per Share memiliki asymp. sig. (2-tailed) sebesar 0,061 berada di atas 0,05 sehingga data terdistribusi normal.

\section{Uji Multikolinearitas}

Uji mulitikolinearitas dilakukan untuk menguji apakah model regresi ditemukan adanya korelasi antar variabel bebas (independen). Model regresi yang baik seharusnya tidak terjadi korelasi di antara variabelindependen. Berdasarkan hasil perhitungan dari program SPSS untuk menguji Multikolinieritas, maka diperolehhasil output sebagai berikut: 
Wirda Lilia, A. Surya Raj, Jesica dan Faren Goh, Pengaruh Return on Asset, Return on Equity dan Earning Per Share Terhadap Harga Saham pada Perusahaan Sektor Barang Konsumsi Yang Terdaftar di Bursa Efek Indonesia

Tabel 3. Hasil Uji Multikolinieritas Sesudah Transformasi Model Collinearity Statistics Tolerance

\begin{tabular}{l|l|l}
\hline 1 & (Constant) & \\
\hline Ln_ROA & .124 & 8.042 \\
\hline Ln_ROE & .124 & 8.068 \\
\hline Ln_EPS & .699 & 1.431 \\
\hline
\end{tabular}

Berdasarkan Tabel diatas dapat disimpulkan bahwa nilai tolerancedan VIF data Return on Asset, Return on Equity, Earning Per Share menunujukkan tidak terjadi multikolinearitas sebab lebih besar dari 0,1 dan lebih kecil dari 10.

\section{Uji Autokorelasi}

Uji autokorelasi digunakan untuk menguji apakah dalam sebuah model regresi linear ada korelasi antara kesalahan pengganggu pada periode $t$ dengan periode $\mathrm{t}-1$ (periode sebelumnya). Salah satu ukuran dalam menentukan ada tidak nya masalah autokorelasi dengan uji Durbin-Watson(DW-test). Berikut hasil uji autokorelasi dengan uji Durbin Watson:

Tabel 4. Hasil Uji Autokorelasi Sesudah Transformasi

\begin{tabular}{cc|ccc|c} 
Model & R & R Square & Adjusted R Square & Std. Error of the Estimate & Durbin-Watson \\
\hline 1 & $.834^{\mathrm{a}}$ & .696 & .687 & .90128 & 1.595 \\
\hline
\end{tabular}

a. Predictors: (Constant), Ln_EPS, Ln_ROA, Ln_ROE

b. Dependent Variable: Ln_HargaSaham

Dari tabel diatas menunjukkan nilai Durbin Watson (DW) untuk data Return on Asset, Return on Equity, Earning Per Share sebesar 1,595. Nilai du = 1,736 dengan jumlah sampel 105 rumus $\mathrm{du}<\mathrm{dw}<4-\mathrm{du}$ sehingga $1,736>1,595<4-1,736 \quad$ kemudian $1,736>1,595<2,264$ menunjukkan terjadinya autokorelasi sehingga dilakukan pengobatan dengan menggunakan run-test:

Tabel 5. Runs Test Unstandardized Residual

Test Value ${ }^{\mathrm{a}}$

Cases < Test Value

Cases $>=$ Test Value

Total Cases

Number ofRuns

$\mathrm{Z}$

Asymp. Sig. (2-tailed) a. Median

Dari tabel di atas menunjukkan asymp sig. runs test sebesar 0,281>0,05, maka data tidak terjadi autokorelasi.

\section{Uji Heteroskedastisitas}

Uji Heteroskedastisitas berguna untuk menguji apakah dalam model regresi terjadi ketidaksamaan varian dari residual satu pengamatan ke pengamatan yang lain. Cara pengambilan keputusan adalah dengan melihat grafik Scatterplot sebagai berikut

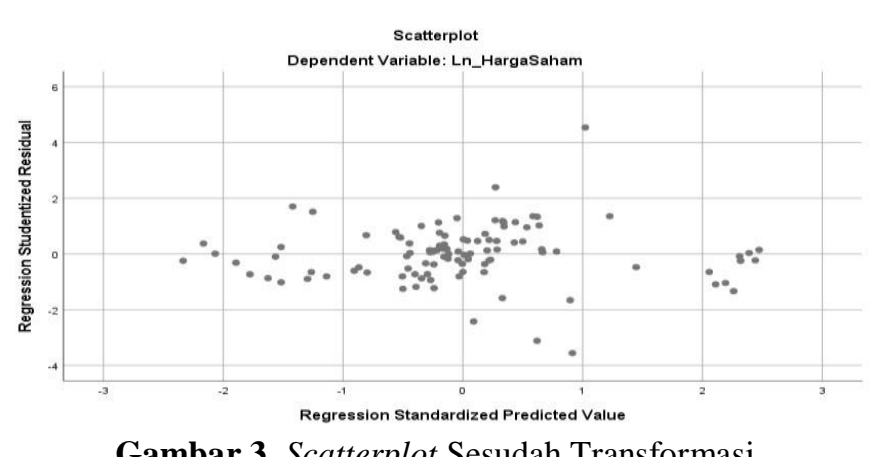

Gambar 3. Scatterplot Sesudah Transformasi

Berdasarkan Gambar 3 menunjukkan bahwa data tersebar secara acak dan tidak membentuksuatu polatertentu. Data tersebar diatas dan dibawah garis 0 yang menunjukkan tidak terjadi heteroskedastisitas.PengujianGlejser dapat disajikan pada Tabel 6 berikut :

Tabel 6. Hasil Uji Glejser Sesudah Transformasi Coefficients $^{a}$

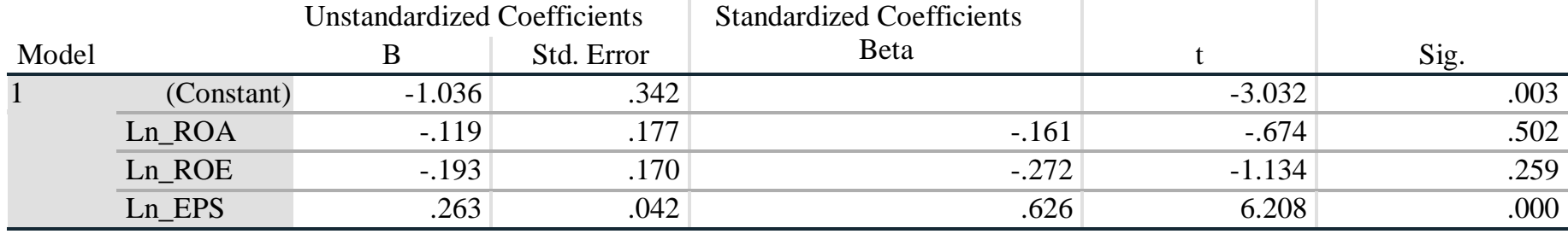

a. Dependent Variable: Abs_ut1

Berdasarkan Tabel 6 diatas menunjukkan nilai signifikan data Return on Asset, Return on Equity berada 
Wirda Lilia, A. Surya Raj, Jesica dan Faren Goh, Pengaruh Return on Asset, Return on Equity dan Earning Per Share Terhadap Harga Saham pada Perusahaan Sektor Barang Konsumsi Yang Terdaftar di Bursa Efek Indonesia

di atas 0,05 disimpulkan tidak terjadi heteroskedastisitas. Sedangkan untuk uji statistik dapat heteroskedastisitas dan Earning Per Share berada di bawah $\quad 0,05 \quad$ disimpulkan terjadi dilakukan dengan uji white pada tabel 7 berikut ini:

Tabel 7. Hasil Uji White Model Summary ${ }^{b}$

\begin{tabular}{lr|r|rr|r} 
Model & R & R Square & Adjusted R Square & \multicolumn{2}{|c|}{ Std. Error of the Estimate } \\
\hline 1 & $.808^{\mathrm{a}}$ & .652 & .642 & 34180789812898596.00000 \\
\hline
\end{tabular}

a. Predictors: (Constant), EPS2, ROE2, ROA2

b. Dependent Variable: U2T

Berdasarkan Tabel di atas menunjukkan bahwa nilai $\mathrm{R}$ sebesar 0,808 dengan perhitungan $\mathrm{c}^{2}$ sebagai berikut:

$$
\begin{aligned}
\mathrm{c}^{2} & =\mathrm{n} \times \text { nilai } \mathrm{R} \\
& =105 \times 0,808 \\
& =84,84 \\
\mathrm{c}^{2} & =84,84>77,93
\end{aligned}
$$

Berdasarkan hasil uji white menunjukkan $\mathrm{c}^{2}>\mathrm{c}^{2}$ tabel maka 84,84>77,93tidak terjadi heteroskedastisitas.

\section{Analisis Regresi Linier Berganda}

Analisis regresi linear berganda digunakan untuk memprediksi perubahan (naikturunnya) variabel dependen yang dihubungkan oleh dua / lebih variabel independen sebagai faktor prediktor yang dimanipulasi dan untuk mengetahui ada tidaknya pengaruh antara variabel independen terhadap variabel dependen. Hasil analisis regresiberganda dapat dilihat pada tabel 8

\begin{tabular}{|c|c|c|c|c|c|c|}
\hline \multirow{2}{*}{\multicolumn{2}{|c|}{ Model }} & \multicolumn{2}{|c|}{ Unstandardized Coefficients } & \multirow{2}{*}{$\begin{array}{c}\text { Standardized Coefficients } \\
\text { Beta }\end{array}$} & \multirow[b]{2}{*}{$\mathrm{T}$} & \multirow[b]{2}{*}{ Sig. } \\
\hline & & $\mathrm{B}$ & Std. Error & & & \\
\hline 1 & (Constant) & .818 & .570 & & 1.435 & .154 \\
\hline & Ln_ROA & -.301 & .295 & -.159 & -1.020 & .310 \\
\hline & Ln_ROE & 1.283 & .283 & .706 & 4.526 & .000 \\
\hline & Ln_EPS & .418 & .071 & .389 & 5.927 & .000 \\
\hline
\end{tabular}
berikut ini:

Tabel 8. Hasil Analisis Regresi Linier Berganda Coefficients $^{a}$

a. Dependent Variable: Ln_HargaSaham

Berdasarkan table 8 diatas diperoleh rumus regres:

Ln_Harga Saham $=0,818-0,301$ Ln_ROA + 1,283 Ln_ROE + 0,418Ln_EPS

Keterangan:

1. Nilai a sebesar 0,818 berarti ReturnonAsset, Return on Equity, Earning Per Share dianggap konstan, maka harga saham 0,818 .

2. Nilai koefisien Return on Asset adalah -0,301. Ini menunjukkan bahwa setiap peningkatan Return on Asset satu kali maka harga saham akan mengalami penurunan sebesar 0,301. Perusahaan tidak dapat menghasilkankeuntungan dengan aset yang dimiliki yang dapat menguntungkan pemegang saham. Kenaikan Return on Asset tidak mempengaruhi kenaikan harga saham hal ini disebabkan keuntungan yang dihasilkan tidak menguntungkan pemegang saham sehingga tingkat kepercayaan investor tidak melihat Return on Asset.

3. Nilai koefisien Return on Equity sebesar 1,283. Ini menunjukkan bahwa setiap peningkatan Return on
Equity satukali maka harga sahamakan mengalami peningkatan sebesar 1,283.

4. Nilai koefisien Earning Per Share sebesar 0,418 ini menunjukkan bahwa setiap peningkatan Earning Per Share satu kali maka harga sahamakan mengalami peningkatan sebesar 0,418 .

\section{Koefisien Determinasi $\left(\mathbf{R}^{2}\right)$}

Uji koefisien determinasi digunakan untuk mengukur seberapa besar kemampuan pengaruh variabel bebas dapat menjelaskan variableel terikat.Semakin besar nilai koefisien determinasi, maka semakin baik kemampuan varian dan variabel bebas menerangkan variable terikat.Berikut ini nilai koefisien determinasi: 
Tabel 9. Koefisien Determinasi

\begin{tabular}{|c|c|c|c|c|}
\hline \multirow[b]{2}{*}{ Model } & \multicolumn{3}{|c|}{ Model Summary ${ }^{b}$} & \multirow[b]{2}{*}{ Std. Error of the Estimate } \\
\hline & $\mathrm{R}$ & R Square & Adjusted R Square & \\
\hline 1 & $.834^{\mathrm{a}}$ & .696 & .687 & .90128 \\
\hline
\end{tabular}

a. Predictors: (Constant), Ln_EPS, Ln_ROA, Ln_ROE

b. Dependent Variable: Ln_HargaSaham

Berdasarkan Tabel diatas diperoleh nilai adjusted $R$ Square $\left(\mathrm{R}^{2}\right)$ koefisien determinasi sebesar 0,687 atau sama dengan $68,7 \%$. variabel independen berpengaruh terhadap harga saham sebesar $68,7 \%$ dan sisanya $31,3 \%$ dipengaruhi variabel lain seperti likuiditas, leverage dan ukuran perusahaan.

\section{Pengujian Hipotesis Secara Simultan (Uji Statistik F)}

Uji F digunakan untuk menguji apakah variabel independen secara bersama-sama mempengaruhi variabel dependen. Berdasarkan hasil uji $F$ dari pengolahan data dengan program SPSS, maka diperoleh sebagai berikut:

Tabel 10. Hasil Uji Statistik F

ANOVA ${ }^{a}$

\begin{tabular}{ll|r|r|r|r|r} 
Model & & Sum of Squares & Df & Mean Square & F & Sig. \\
\hline \multirow{2}{*}{1} & Regression & 187.512 & 3 & 62.504 & 76.946 & $.000^{\mathrm{b}}$ \\
\cline { 2 - 7 } & Residual & 82.043 & 101 & .812 & \\
\cline { 2 - 7 } & Total & 269.555 & 104 & & \\
\hline
\end{tabular}

a. Dependent Variable: Ln_HargaSaham

b. Predictors: (Constant), Ln_EPS, Ln_ROA, Ln_ROE

Dari Tabel 10,bisa dilihat hasil $F_{\text {hitung adalah }}$ sebesar 76,946 dengan nilai signifikan 0,000 sedangkan $F_{\text {tabel }}(105-4=101)$ adalah sebesar 2,69 maka $F_{\text {hitung }}>F_{\text {tabel }}$ yaitu 76,946> 2,69 sehingga keputusan Ho ditolak dan Ha diterima, artinya variabel Return on Asset, Return on Equity dan EarningPerShare berpengaruh Terhadap Harga Saham pada Perusahaan Sektor Barang Konsumsi yang Terdaftar di Bursa Efek Indonesia.

\section{Pengujian Hipotesis Secara Parsial (Uji Statistik t)}

Uji t digunakan untuk menguji apakah variabel independen secara individual mempengaruhi variabeldependen.Berdasarkan hasil pengolahan data dengan program SPSS, maka diperoleh hasil uji $\mathrm{t}$ sebagai berikut:

Tabel 11. Hasil Uji Statistik t Coefficients ${ }^{a}$

\begin{tabular}{|c|c|c|c|c|c|}
\hline \multirow[b]{2}{*}{ Model } & \multicolumn{2}{|c|}{ Unstandardized Coefficients } & \multirow{2}{*}{$\begin{array}{c}\text { Standardized Coefficients } \\
\text { Beta }\end{array}$} & \multirow[b]{2}{*}{$\mathrm{t}$} & \multirow[b]{2}{*}{ Sig. } \\
\hline & $\mathrm{B}$ & Std. Error & & & \\
\hline 1 (Constant) & .818 & .570 & & 1.435 & .154 \\
\hline Ln_ROA & -.301 & .295 & -.159 & -1.020 & .310 \\
\hline Ln_ROE & 1.283 & .283 & .706 & 4.526 & .000 \\
\hline Ln_EPS & .418 & .071 & .389 & 5.927 & .000 \\
\hline
\end{tabular}

a. Dependent Variable: Ln_HargaSaham

\section{SIMPULAN}

1. Variabel Return on Asset mempunyai nilai $t_{\text {hitung }}$ sebesar -1,020 dengan nilai signifikan 0,310 sedangkan $\mathrm{t}_{\text {tabel }}(105-103=102)$ adalah sebesar 1,983 . $-\mathrm{t}_{\text {hitung }}>$ - $\mathrm{t}_{\text {tabel }}$ yaitu $1,020>1,983$ maka keputusannya Ho diterima dan $\mathrm{H}_{\mathrm{a}}$ ditolak dengan nilai signifikan 0,310 berada di atas 0,05 menunjukkan Return on Asset tidak berpengaruh terhadap harga saham pada perusahaan barang konsumsi yang terdaftar di Bursa Efek Indonesia.

2. Variabel Return on Equity mempunyai nilai $t_{\text {hitung }}$ sebesar 4,526 dengan nilai signifikan 0,000 sedangkant table $(105-3=102)$ adalah sebesar 1,983 . $t_{\text {hitung }}>\mathrm{t}_{\text {tabel }}$ yaitu 4,526 $>1,983$ maka keputusannya
Ho ditolak dan $\mathrm{H}_{\mathrm{a}}$ diterima dengan nilai signifikan 0,000 berada di bawah 0,05 menunjukkan Return on Equity berpengaruh terhadap harga saham pada perusahaan barang konsumsi yang terdaftar di Bursa Efek Indonesia.

3. Variabel Earning Per Share mempunyai nilai $t_{\text {hitung }}$ sebesar 5,927 dengan nilai signifikan 0,000 sedangkant tabel $(105-3=102)$ adalah sebesar 1,983 . $\mathrm{t}_{\text {hitung }}>\mathrm{t}_{\text {tabel }}$ yaitu 5,927 $>1,983$ maka keputusannya Ho diterima dan $\mathrm{H}_{\mathrm{a}}$ ditolakdengan nilai signifikan 0,004 berada di bawah 0,005 menunjukkan Earning Per Share berpengaruh terhadap harga saham pada perusahaan barang konsumsi yang terdaftar di Bursa Efek Indonesia. 


\section{DAFTAR PUSTAKA}

Alipudin, Asep dan Resi Oktaviani. 2016. Pengaruh Eps, Roe, Roa Dan Der Terhadap Harga Saham Pada Perusahaan Sub Sektor Semen Yang Terdaftar Di BEI.JIAFE (Jurnal Ilmiah Akuntansi Fakultas Ekonomi). Volume 2 No. 1 Tahun 2016 Edisi 1, Hal. 1-22. Universitas Pakuan.

Fahmi, Irham. 2014. Pengantar Manajemen Keuangan. Bandung : Penerbit Alfabeta

Fauza dan Mustanda.2016.Pengaruh Profitabilitas, Earning Per Share (Eps) Dan Dividend Payout Ratio (Dpr) Terhadap Harga Saham.E-Jurnal Manajemen Unud. Vol. 5 No. 12, 2016 : 80158045. ISSN : 2302-8912.

Ghozali, Imam.2018. Aplikasi Analisis Multivariate Dengan Program IBM SPSS 25.Jakarta : Penerbit Universitas Diponegoro

Ika dan Wardiyani.2015.Pengaruh Kinerja Keuangan Terhadap Harga Saham Pada Perusahaan Terindeks Kompas 100 Yang Terdaftar Di Bursa Efek Indonesia.EFEKTIF Jurnal Bisnis dan Ekonom. E-ISSN 2503 - 2968. Universitas Janabadra.

Ircham, Handayani dan Saifi.2014. Pengaruh Struktur Modal Dan Profitabilitas Terhadap Harga Saham (Studi pada Perusahaan Makanan dan Minuman yang terdaftar di Bursa Efek Indonesia Tahun 2009-2012. Jurnal Administrasi Bisnis (JAB). Vol 11 No. 1 Juni 2014. Malang : Universitas Brawijaya.

Kasmir.2014.Analisis Laporan Keuangan. Cetakan Keempat. Jakarta : Penerbit Rajagrafindo Persada.

Murhadi, Werner. 2013.Analisis Laporan Keuangan Proyeksi dan ValuasiSaham. Jakarta : Penerbit Salemba Empat Nugroho

Nur'aidawati, Siti. 2018. Pengaruh Current Ratio (CR), Total Asset Turnover (TATO), Debt To Equity Ratio (DER) Dan Return On Asset (ROA) Terhadap Harga Saham Dan Dampaknya Pada Nilai Perusahaan (Studi Kasus pada Sepuluh Bank Terbesar yang terdaftar di Bursa Efek Indonesia Periode Tahun 2011 2015).JurnalSekuritas. Vol.1, No.3, Maret 2018. Universitas Pamulang.

Rahmadewi, Pande Widya dan Nyoman Abundati.2018. Pengaruh EPS, PER, CR, Dan ROE Terhadap Harga Saham Di Bursa Efek Indonesia.E-Jurnal Manajemen Unud, Vol.7, No. 4, 2018: 2106-2133. Bali : Universitas Udayana.

Zulfi, Isynuwardhana dan Nurbaiti. 2016. Pengaruh Economic Value Added, Return on Equity, Return on Assets dan Earning Per Share Terhadap Harga Saham (Pada Perusahaan Manufaktur Sektor Industri Barang Konsumsi yang terdaftar di Bursa Efek Indonesia Tahun 2012-2014).eProceeding of Management : Vol.3 No.3 Desember 2016. ISSN : 2355-9357. Universitas Telkom. 